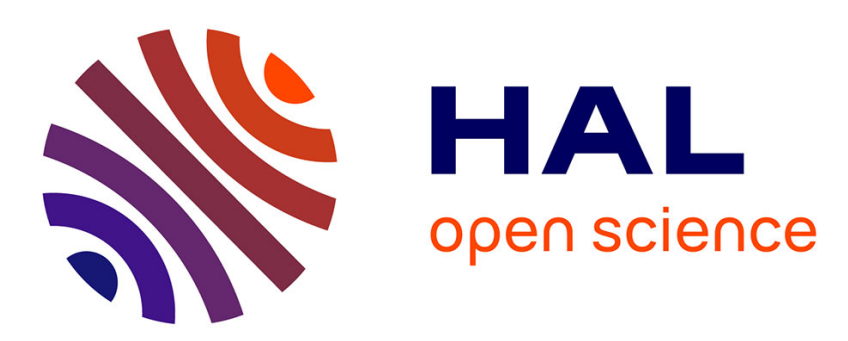

\title{
Consumer Attitudes Toward Cross-Cultural Products in Convenience Stores: A Case Study of Japanese Food in Thailand
}

\author{
Supimmas Thienhirun, Sulin Chung
}

\section{To cite this version:}

Supimmas Thienhirun, Sulin Chung. Consumer Attitudes Toward Cross-Cultural Products in Convenience Stores: A Case Study of Japanese Food in Thailand. IFIP International Conference on Advances in Production Management Systems (APMS), Sep 2015, Tokyo, Japan. pp.129-135, 10.1007/978-3-319-22756-6_16. hal-01417451

\author{
HAL Id: hal-01417451 \\ https://hal.science/hal-01417451
}

Submitted on 15 Dec 2016

HAL is a multi-disciplinary open access archive for the deposit and dissemination of scientific research documents, whether they are published or not. The documents may come from teaching and research institutions in France or abroad, or from public or private research centers.
L'archive ouverte pluridisciplinaire HAL, est destinée au dépôt et à la diffusion de documents scientifiques de niveau recherche, publiés ou non, émanant des établissements d'enseignement et de recherche français ou étrangers, des laboratoires publics ou privés.

\section{(c)(1)}

Distributed under a Creative Commons Attribution| 4.0 International License 


\title{
Consumer Attitudes toward cross-cultural products in convenience stores: A case study of Japanese food in Thailand
}

\author{
Supimmas Thienhirun and Sulin Chung* \\ Industrial Engineering and Management, Graduate School of Decision Science and \\ Technology, Tokyo Institute of Technology, Tokyo 152-8550, Japan \\ thienhirun.s.aa@m.titech.ac.jp
}

\begin{abstract}
Recently, cross-cultural products are distributed to various countries. In Thailand, Japanese products are popular, especially food. Most of Thai people normally consume Japanese food in restaurants and street markets. On the other hand, Japanese food in convenience stores is not sold well comparing to Japan. In order to increase the sales of cross-cultural products, a case study of Japanese food has been conducted in order to understand consumer culture and behavior. Therefore, this research has investigated the attitudes and factors affected on decision making towards consuming Japanese food. Firstly, one-to-one interview is conducted to reveal consumer perception and behavior. Secondly, conjoint analysis is used to figure out importance values from consumer point of view.
\end{abstract}

Keywords: cross-cultural, Japanese food, convenience store

\section{$1 \quad$ Introduction}

When the world becomes globalization, the barrier across national boundary has been reduced. Various kinds of cross-cultural products are exported to other countries in order to expand business and introduce its own culture. Currently, ASEAN is one of growing markets that foreign investors are interested, especially, consumer goods. From the statistical survey across ASEAN countries, Thailand is classified as a promising market among other countries, the market size is large and has high potential of market growth rate [1]. Furthermore, around 30 percent of Thai population in 2015 will belong to the group of medium to high income people which account for 20.63 million. These people are the main

\footnotetext{
* Corresponding author
} 
target who can afford cross-cultural products which are sold more expensive than local products. Therefore, selling cross-cultural products in Thailand tends to increase.

Due to the city life, people's lifestyle has been shifted from home-cooking to eating out. Therefore, the number of consumers who eat outside has been increased. With the popularity of Japanese trend, various kind of Japanese food are sold in restaurants and café, especially at the center of the city. Many campaigns and promotions are launched to boost up sales. Likewise, convenience stores also adapt Japanese strategies and launch campaigns related to Japanese mascots such as Hello Kitty and Doraemon. Recently, different kinds of Japanese foods and sweets are already available on shelf for consumers. Recently, in some branches of convenience stores in Bangkok has started offer made-to-order Japanese meals such as Udon, Katsudon and Chicken Teriyaki with a few seats inside the stores [2]. Therefore, consumers can sit and eat inside the provided area in a store for 24 hours.

Even though Japanese food has become more popular in Thailand, Japanese food in convenience stores is not yet well recognized. Therefore, this paper has investigated the consumer attitudes toward Japanese food and identified the key factors of Japanese readyto-eat food in order to increase the sale in convenience stores.

\section{Cross-cultural research}

Cross-cultural refers to the difference in cultures. Each country has unique or traditional culture which belongs to a specific group and passes from one generation to another generation by learning [3]. Hofstede and Minkov further stated in the dimensions of national cultures that some countries have different culture although they located in the same continent. For example, in Asia, Japan leans to individualism while Thailand leans to collectivism. From 1970 to present, many papers related to cross-cultural study between customer attitude and behavioral comparison have been published $[5,6]$. The study of factors affected purchasing of new food comparing between U.K. and Chinese consumers showed that healthy and food quality were revealed as the primary factors for both countries [7]. Besides, in the study of predicting consumer's aesthetic taste for cultural products, the researchers found that consumers who are past oriented trend to prefer cultural product of old generation [8]. Thus, making these group of consumers adapt to cross-cultural products might be a challenging issue. Cross-cultural products can be referred as the products come from other countries that have different cultures. However, these products might be made in originated countries or other countries but still represent the culture from origins. For 
example, Onigiri, the traditional Japanese rice ball wrapped with dry seaweed is sold widely in various countries but consumers still perceive this product originated from Japan [4]. When the products are not fitted with consumer culture, it leads to the loss in business. For example, Walmart, a big retailer in U.S. used to cooperate with 7-11 in Japan and had introduced some products such as tomato sauce and Jam to Japanese consumers. However, these products were not sold well because the size of tomato sauce $(1,000 \mathrm{ml}$.) is too big and the taste of Jam is too sweet for Japanese consumers [9]. In addition, characteristics of Japanese consumer might be different from U.S. consumers as they put more emphasis on small packaging and product quality more than low-price products. In addition, when environment and situation change, consumer preferences have changed as well [10].

\section{Trend of Japanese food in retail store in Thailand}

Typically, retail stores can be classified as traditional and modern retailing. In Thailand, modern retailing is accounted for approximately 40 percent of retail market [1]. This type includes supermarkets, hypermarkets, department stores, shopping malls and convenience stores. On the other hand, traditional retailing includes fresh food markets, nearby traditional small stores and grocery stores. In urban areas, majority are small retail stores due to the high land price, while in rural areas the stores are larger. Comparing among modern retailing types in Table 1, convenience stores revealed the highest percent rate of use with the approximate purchase frequency 16.4 times per month among others. Furthermore, classification of Japanese products for each location has been shown including fresh ingredients, ready-to-eat foods, made-to-order foods, snacks and drinks. With the culture and lifestyle, traditional retail stores often sell Thai products rather than crosscultural products. However, only snacks and drinks are available in some branches of grocery stores around city areas. In fresh food market, only some places sell fresh ingredients from Japan to the customers such as sweet potato, saba and salmon. For modern retailing group, department store and shopping mall normally sell all 5 types of Japanese products. However, supermarket and hypermarket do not offer made-to-order Japanese food, while it is available in some branches of convenience stores.

In Thailand, especially Bangkok, various kind of Japanese restaurants in department stores are opened nowadays which are mostly recognizing brands from Japan where focused on healthy and fresh cuisine. Recently, as convenience stores in some branches offer similar products as sold in Japan such as bento box and made-to-order Japanese meals, the sales of the stores have been increased but not as high as in Japan. 
Table 1. Comparing purchase frequency and available Japanese products between traditional and modern retailing (adapted from Kawazu, 2013; data collected from

October to November 2011)

\begin{tabular}{|c|c|c|c|c|c|c|c|c|}
\hline \multirow{2}{*}{ Thailand } & \multicolumn{3}{|c|}{ Traditional Retailing } & \multicolumn{4}{c|}{ Modern Retailing } \\
\cline { 2 - 9 } & $\begin{array}{c}\text { Fresh } \\
\text { food } \\
\text { market }\end{array}$ & $\begin{array}{c}\text { Nearby } \\
\text { traditional } \\
\text { store }\end{array}$ & $\begin{array}{c}\text { Grocery } \\
\text { store }\end{array}$ & $\begin{array}{c}\text { Super } \\
\text { market }\end{array}$ & $\begin{array}{c}\text { Hyper } \\
\text { market }\end{array}$ & $\begin{array}{c}\text { Department } \\
\text { store }\end{array}$ & $\begin{array}{c}\text { Shopping } \\
\text { mall }\end{array}$ & $\begin{array}{c}\text { Conve } \\
\text { nience } \\
\text { store }\end{array}$ \\
\hline $\begin{array}{c}\text { Purchase } \\
\text { frequency }\end{array}$ & 11.0 & 6.7 & 15.7 & 3.2 & 3.2 & 1.9 & 2.0 & 16.4 \\
\hline $\begin{array}{c}\text { Available } \\
\text { product }\end{array}$ & $\mathrm{F}^{*}$ & None & $\mathrm{S}^{*}, \mathrm{D}^{*}$ & $\begin{array}{c}\text { FTE, } \\
\text { RT, }\end{array}$ & $\begin{array}{c}\text { RTE, } \\
\text { S, D }\end{array}$ & All & All & $\begin{array}{c}\text { RTE, } \\
\text { MTO } \\
\text { S,D }\end{array}$ \\
\hline
\end{tabular}

F: $\quad$ Fresh materials imported from Japan such as seafood and vegetables

RTE: $\quad$ Ready-to-eat Japanese foods refer to food which is packed in a package.

The customers can open and eat it immediately or/and warm it before eating.

MTO: Made-to-order Japanese foods refer to food which is cooked after customer ordering

S: $\quad$ Japanese snacks and desserts

D: $\quad$ Drink category such as Japanese Green tea and Hokkaido milk

Remark* means a product is available in some branches.

\section{Survey of consumer attitudes toward Japanese food in Thailand}

In this research, the data were gathered by using interview method. 34 people who worked and lived in Bangkok areas were interviewed one by one for approximately 20 minutes because only branches of convenience in Bangkok sell made-to-order and ready-to-eat Japanese food. The outline of interview was mainly divided into 4 sections; (1) made to order food and (2) ready to eat food in convenience stores, (3) made to order food and (4) ready to eat food in other places except convenience stores. Firstly, participants were briefly explained about the outline of the interview. After that the participants were asked whether they get familiar with Japanese food or not in order to classify participant background. Moreover, before conducting this survey, pilot test had been done to figure out the problem during the interview which lead to an improvement of the interview question and outline structure.

In each section of the interview, the participants were asked to write about 3 things related to the topic about Japanese food in different places if they have tried it before. For example, "Write down 3 things when thinking about made-to-order Japanese food in convenience stores". However, if participants never try it, they will not be requested to answer this question. In addition, they were asked about what kind of Japanese food they eat, where 
and when they normally had Japanese food. In the last part of the interview, 9 cards from conjoint analysis related to ready-to-eat Japanese food had been shown to the participants and let them rank the most to the least preferable card themselves. Conjoint analysis is the popular method used in market research to identify the key attributes from customer viewpoint [11]. Therefore, in this research 4 attributes were selected in which each attribute has 3 levels as presented in Table 2. The examples of the card are presented in Figure 1.

Table 2. Attributes in conjoint analysis

\begin{tabular}{|c|c|c|c|c|}
\hline $\begin{array}{l}\text { Attribute } \\
\text { Level }\end{array}$ & Price & Taste & Design & Calories \\
\hline 1 & Low (10-30 Baht) & Japanese & Clear plastic & Less $(<400 \mathrm{Kcal})$ \\
\hline 2 & Medium (31-50 Baht) & Thai & Letter & Medium (401-800 Kcal) \\
\hline 3 & High (51-70 Baht) & Mixed & Colorful picture & High $(>801 \mathrm{Kcal})$ \\
\hline
\end{tabular}

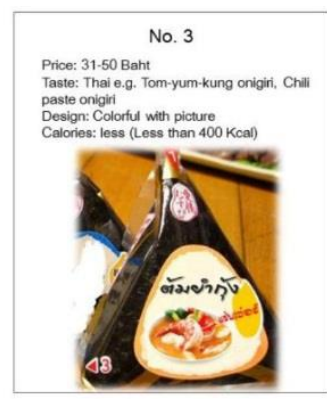

(a)

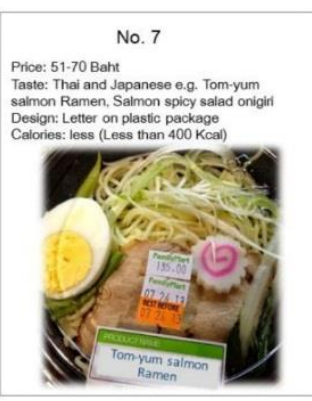

(b)

Fig. 1. Examples of conjoint cards (a) adapted from http://www.catdumb.com (b) adapted from www.quitecurious.com

\section{$5 \quad$ Result and Discussion}

From the interview, majority of participants consumed made-to-order Japanese food every month. Most of them explained that Japanese food was quite expensive. Therefore, they normally ate it on occasion with family or friends at Japanese restaurants around both city areas and in department stores. However, some of participants who really love Japanese food mentioned that they ate it every week. Around 70 percent of participants ate made-toorder Japanese food for dinner after work and for lunch or dinner during weekend because they had plenty of time to enjoy meals at the restaurants. Approximately 50 percent of participants have tried ready-to-eat Japanese food at street markets while 35 percent 
purchased at supermarkets. Most of them consumed it for lunch and dinner but seldom ate it because they perceived it was not fresh and tasty. Besides, they mentioned that the quality of the product was not good. Similar to the result of ready-to-eat Japanese food in convenience stores, the participants claimed it did not look tasty. They explained further that consuming ready-to-eat food was not good for their health because they thought that it contained preservative and was not fresh. Therefore, only 40 percent of participants bought ready-to-eat Japanese food at convenience stores mostly in the afternoon and at night when they were really hurry. Lastly, as convenience stores in Thailand recently launched madeto-order Japanese food, the result revealed that less than 10 percent of participants tried it in which most of them ate it for breakfast and lunch. Some participants did not know that the convenience stores offer made-to-order Japanese food and in Bangkok due to only a few branches of convenience stores sell this products. However, participants who knew but did not try it because they thought that the food might not be tasty and expensive comparing to made-to-order Thai food in street markets and canteens.

After asking participants about the first 3 things when thinking about made-to-order Japanese food in other places except convenience stores, 35 words were collected. The most frequent mentioned words were sushi, sashimi, salmon, tasty and expensive as shown in Figure 2. For ready-to-eat Japanese food in convenience stores and other places, most of the participants wrote about onigiri, sushi and convenience. As a few participants tried made-to-order Japanese food in convenience stores, only 2 repeated words were collected, katsudon and udon. This result showed that most of the participants recognized sushi and sashimi as representative made-to-order Japanese food in the restaurants and street markets which quite expensive. In contrast, katsudon and udon were written because the participants might try these made-to-order food in convenience stores. Besides, onigiri and convenience were the most mentioned word about ready-to-eat Japanese food regardless of any location.

The result of conjoint analysis showed that the taste was the most important value among other attributes, followed by design, price and calories (Table 3). Furthermore, card number 7 as shown in Figure 1 had the highest total utility of $6.303\left(\mathrm{Y}_{7}=5.078\right.$ $0.118+0.784+0.284+0.275)$. With this result, ready-to-eat Japanese food sold in convenience stores should be emphasized on the taste of the product in order to match with Thai preference. This result is corresponding with the study of customer perception about chain restaurants in Bangkok, in which taste was the second concerned attributes apart from the convenience location [12]. The taste of Japanese and Thai flavor was found as the highest utility score. In contrast, the product with Thai flavor only was not preferable because the participants were able to find it on street market and in office canteen. Besides, 
some participants preferred authentic Japanese taste because it was hard to find traditional Japanese cuisine in Thailand. For packaging, the letter label on a transparent packaging was preferred to leave space for showing product inside. The participants mentioned that when the product was made with a good taste and they could see the ingredients inside a package with a nice label, they preferred to buy it. The price and calories were revealed in the same direction, the less number of calories and price was preferred. Also, majority of participants also mentioned that the ready-to-eat food should be fresh and does not contain preservative.

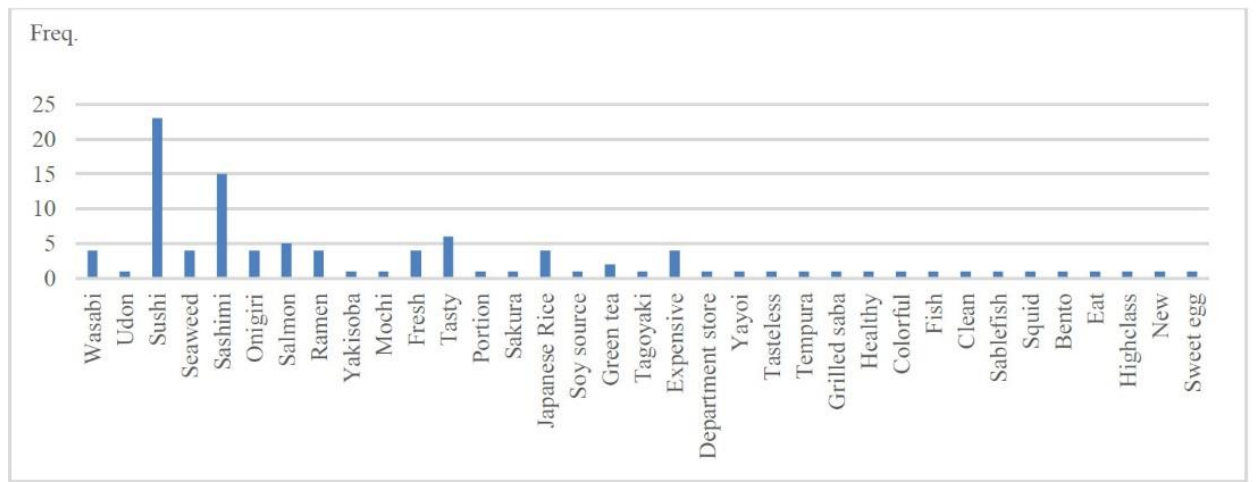

Fig. 2. The frequency of mentioned words about made-to-order Japanese food in other places except convenience stores

Table 3. Importance value from conjoint analysis

Importance Values
\begin{tabular}{|l|l|}
\hline Taste & 27.799 \\
Design & 24.932 \\
Calories & 23.066 \\
Price & 24.203 \\
\hline
\end{tabular}

\section{Conclusion}

This research presents attitudes of consumer toward cross-cultural product, Japanese food in convenience stores. From this study, the important factors when consumers make a decision to buy Japanese food related to intrinsic values including freshness, taste and health. The result from conjoint analysis for ready-to-eat food showed both taste and design were 
precedence over others which was analogous with the result from past literature reviews $[7,12]$. Besides, one cultural reason that Thai consumers did not commonly purchase Japanese food in convenience stores in Bangkok related to collectivism. Most of consumers normally eat with friends and family at the restaurants or canteen while only a few seats available in convenience stores. In a contrast, Japanese are individualism which means consumers tend to eat individually. As this study limited participants only in Bangkok, the future research will focus on a large nationwide survey and applying choice architecture tools to influence consumer to consume more Japanese food in convenience stores.

\section{$7 \quad$ References}

1. Kawazu, N.: Consumer trends and expansion of retail markets in growing ASEAN economies. Nomura research institute, 6-13 (2013)

2. Easybiznezz, http://www.easybiznezz.com

3. Hofstede, G., Hofstede G.J., Minkov, M.: Culture and organization: Software of the mind, New York (2010)

4. Stack Exchange, http://japanese.stackexchange.com

5. Guerrero, L et al.: Consumer-driven definition of traditional food products and innovation in traditional foods. A qualitative cross-cultural study. Appetite. 52, 345-354 (2009)

6. Nagashima, A.: A comparison of Japanese and U.S. attitudes toward foreign products. J MARKETING. 34, 68-74 (1970)

7. Eves, A., Cheng, L.: Cross-cultural evaluation of factors driving intention to purchase new food products- Beijing, China and south-east England. Int J Consum Stud. 31, 410417 (2007)

8. Holbrook, M.B, Schindler, R.M.: Age, sex and attitude toward the past as predictors of consumers' aesthetic tastes for cultural products. J MARKETING RES. 31, 412-422 (1994)

9. Yoshinobu, S.: International retailing plans and strategies in Asia: Some reasons why foreign retailers have difficulties in succeeding in the Japanese market, New York (2004)

10. Yau, O.H.M.: Consumer behavior in China: Customer satisfaction and cultural value, New York (1994)

11. IBM cooperation: SPSS conjoint 22, 1-10 (2013)

12. Kessuvan, A., Akanit, R.: The perceived service quality of chain restaurants in Bangkok. In: $12^{\text {th }}$ SARD workshop, pp.248-267. Bangkok (2014) 